$71^{\text {st }}$ International Astronautical Congress (IAC) - The CyberSpace Edition, 12-14 October 2020.

Copyright $@ 2020$ by the International Astronautical Federation (IAF). All rights reserved.

IAC-20-E1.6.5 x59480

\title{
COLIBRÍ MISSION: HOW TO BOOST THE MEXICAN SPACE INDUSTRY BY INVOLVING THE GENERAL PUBLIC INTO THE DEVELOPMENT OF A SPACE PROGRAM
}

\author{
Daniela Rodriguez-Martinez ${ }^{a}$, Sonia Robles ${ }^{\mathrm{b} *}$, Carlos Laguna-Juárez \\ ${ }^{a}$ B.A. Communication, Universidad Panamericana, School of Communication, Head of Colibri Mission's \\ Media and Marketing unit, danyrm@outlook.com \\ ${ }^{b}$ Assistant Professor, University of Delaware,Department of History, srobles@udel.edu \\ ${ }^{c}$ M.S Space Engineer, Universidad Panamericana, School of Engineering, Faculty Lead of Colibri Mission, \\ claguna@up.edu.mx \\ * Corresponding Author
}

\begin{abstract}
Colibrí Mission is one of the first space missions developed by undergraduate students in Mexico, which is designing and building a nanosatellite dedicated to scientific research on Earth's Lower Atmosphere. In a country with a nascent space industry, it is important not only to manage and attract talented individuals capable of conducting scientific and technical research, but also to serve key audiences that can contribute to the Mission's fundraising objectives and promote scientific and technological knowledge among Mexican society, in particular its youth. With limited access to government space funding, these outreach programs sustain important sponsor-seeking efforts to bring the Mission to life. Colibrí Mission seeks to make significant contributions to the development of the space industry in Mexico. This paper presents an example of the implementation of transmedia in a space program's communication strategy. The two main objectives -public outreach and fundraising- were achieved by generating brand awareness and managing key specific stakeholders. Adapting a public relations model and utilizing the methodology proposed by Colin Eden and Fran Ackermann (2010) to map stakeholders, Colibrí Mission's strategy seeks to influence key stakeholders to better suit the Mission's needs and transmit the experience of what it means to belong to a Mexican space mission. The implementation of the transmedia strategy resulted in: influencing key stakeholders by increasing their interest to help the team as two context setters moved to key player positions; gaining sponsors and allies that previously did not exist; and an increase in public outreach, brand recognition and followers on social media platforms.
\end{abstract}

Keywords: Colibrí Mission, communication, public outreach, space project, transmedia, stakeholders.

\section{Acronyms/Abbreviations}

Universidad Panamericana (UP)

Space Propulsion Lab at MIT (SPL-MIT).

NASA's Jet Propulsion Lab (JPL-NASA)

Preliminary Design Review (PDR)

Critical Design Review (CDR)

Low-Earth Orbit (LEO)

Systems Engineering (SE)

Public Relations (PR)

Players (PL)

Subjects (SJ)

Crowd (CR)

Context setters (CS)

Integrated marketing communication strategy (IMC)

\section{Introduction}

This paper explains the origins of Colibrí Mission by offering the context of the space industry in which it is developing and describing its vision and objectives. It also explains the importance of branding a space project and the benefits of using transmedia in a public outreach strategy. Finally, it presents significant results that demonstrate the effectiveness of bringing together engineering and communication fields.

\subsection{Background}

The Mexican Space Agency (Agencia Espacial Mexicana, or AEM) was created in July 2010 with five main objectives that focus on developing the Mexican space industry. These include forming specialized human capital, promoting innovation, conducting technological and scientific research involving the private and public sector, investing in infrastructure and strategic projects, and using space technology to meet the needs of the Mexican population [1] [2] [3].

In 2017, the AEM restructured its objectives with the Plan de Órbita 2.0 and identified the need to involve three strategic actors in any project moving forward: industry, the academy, and the government [4].

For their capacity to train engineering and science students from an undergraduate level onward and their state-of-the-art installations, the AEM concluded that 
Mexican private and public universities are necessary [4, p.31]. With their contributions reaching 46\%, Mexico's public sector, moreover, is responsible for close to half of national total spending in science, technology, and innovation [4, p.32].

Finally, in the efforts to create sustainable development for a strong and successful Mexican space industry, what the former AEM director Dr. Mendieta called a "national cluster" [4, p.11], there is a need to unite the existing industries of aeronautics, automotive, IT, and electronics and give them an incentive to work together with the growing number of businesses dedicated to the general topic of space [4, p.34].

And perhaps most importantly, the AEM has been at the forefront in the event that initiated a new era in Mexico's space history: the launch of the country's first $1 \mathrm{U}$ CubeSat and the second small satellite designed by undergraduate students since $1996^{1}$.

AzTechSat-1 was developed by professors and students from the Mexican Universidad Popular Autónoma del Estado de Puebla (UPAEP) and was successfully launched aboard the 19th SpaceX Commercial Resupply Services contract mission in 2019 [6]. To date, it is the first spaceflight collaborative project between NASA's Ames Research Center and the AEM [6][7].

While relatively small in size -four inches per side- the AzTechSat-1 is a testament of Mexico's continued development in space technology and the first satellite designed and built entirely by Mexican university students [6]. Furthermore, AzTechSat-1 is a model for the direction Colibrí Mission seeks to improve: student input in each phase of the project, strong collaboration with international agencies, and successful mission operations.

Currently, Mexico has a growing aeronautics industry whose value reached $\$ 7.2$ billion dollars in 2016 [8]. Furthermore, the country is ranked seventh in a global list of suppliers of aeronautical products and services to the United States [4, p.10]. Together, these figures indicate current wide-ranging opportunities for private and public investment in the Mexican space program.

Over the last decade, Mexico has purchased satellites from foreign companies instead of developing its own technology. However, new developments in the aerospace industry are allowing the democratization of the final frontier. To that end, some of the AEM's current and future goals include the inauguration of the Innovation and Space Development Center and the continuation of the CubeSat missions programs. Moreover, the organization is collaborating with NASA

\footnotetext{
${ }^{1}$ The first Mexican microsatellite went into orbit September 5, 1996 and was the result of collaboration between the Universidad Nacional Autónoma de México (UNAM) and the Moscow Aviation Institute. This post-cold war satellite was
}

and a number of universities in Mexico to launch a constellation in 2023 (tentatively) [9].

The AEM has expressed its continued support to higher education and private-sector space projects in Mexico: the Universidad Panamericana's Colibrí Mission 3U CubeSat one current example.

\subsection{Colibrí Mission}

Misión Colibrí, or Colibrí Mission, is the first space project developed by the Universidad Panamericana (UP) in Mexico in collaboration with the Space Propulsion Lab at MIT (SPL-MIT). Colibrí Mission is an educationalscientific project supported by NASA's Jet Propulsion Lab (JPL-NASA) and the AEM.

A precursor to the project took place in 2018 when the Universidad Panamericana signed a formal agreement with MIT International Science and Technology Initiatives, also known as MISTI, which committed to support Mexican engineering students.

The following year, a group of engineering students traveled to Boston to learn more about Cubesats in the SPL-MIT. The trip was fundamental for what later became Colibrí Mission because the MIT professors with their research assistants together with the Mexican undergraduate students who attended the CubeSat workshop decided that from that moment forward they would collaborate in the construction of a nanosatellite that would adhere to MISTI's objectives.

In the last two years, Colibrí Mission has relied on the input and work of more than thirty undergraduate students in different fields including engineering, communication, design, and law. Furthermore, the team successfully completed its Preliminary Design Review (PDR) in 2019 and is preparing to present its Critical Design Review (CDR) by the end of 2020, important technical benchmarks in the mission's life-cycle.

Colibrí Mission aims to design and build a 3U CubeSat that will measure atmospheric density at Low-Earth Orbit (LEO) and contribute to the mitigation efforts of space debris. Accomplishing these objectives would not only help advance the Mexican space industry but also help introduce new space technology to the world.

Beyond creating a nanosatellite, the project will be a valuable contribution to the Mexican space industry because it will train a new generation of professionals with profound experience in satellite development. In the end, the technological value chain -from design and development to manufacturing and operations- will be fulfilled.

Furthermore, Colibrí Mission will directly align with one of the AEM's main objectives, promoting the expansion

designed by UNAM engineering students to measure the velocity and number of meteors that came into contact with terrestrial atmosphere [5]. 
and consolidation of spatial knowledge, understanding and culture in Mexican society, particularly among its youth [3]. The project is also dedicated to sharing information about the progress and overall experience of building a CubeSat through a number of outreach activities that will provide the general public with accessible information and hopefully awaken interest in space technology among the Mexican population.

Currently, Colibrí Mission faces three major challenges: limited student involvement in a long term-project, designing a satellite in accordance with international standards, and financing, which is crucial, as the project requires resources for its design, construction, launch and operations.

Aside from the group directly responsible for the technical development of the nanosatellite, the Mission includes a Media and Marketing unit in charge of fundraising, communication strategies, and public outreach. A Media and Marketing team adds a multidisciplinary dimension to the project and highlights its uniqueness, as it breaks away from traditional or space project standards.

\subsection{Communicating Colibrí Mission as a Brand}

Public outreach has been taken into account as a factor in satellite development, but was implemented in the final phases of a space project's technical life cycle, as exemplified in NASA's Systems Engineering Handbook [10, p.47].

Educational and public outreach programs are fundamental for the dissemination of space science from an agency such as NASA to the general public. As science journalist Laura Woodmansee has noted, programs engaging the public give way to a "new generation of scientists and engineers, and even artists and writers" [11].

One of Colibrí Mission's social objectives is also public outreach. The leadership team considers it a way in which they can educate and mentor Mexican youth about science and awaken their interest in space technology. Furthermore, Colibrí Mission is a student-run project supported by a relatively young space agency and is reliant on the fundraising campaigns of its team members. In its efforts to break existing scientific boundaries within Mexico, attending and engaging with the general public from its initial stages are fundamental activities for Colibrí Mission.

Because Colibrí Mission is an innovative project seeking to awaken interest among the Mexican people for space science, it requires a communications strategy that considers not only the construction of a nanosatellite but also one that transmits the experience of what it means to belong to a Mexican space mission.

Using the power of branding and implementing a transmedia-marketing strategy, the Media and Marketing team seeks to accomplish Colibrí Mission's fundraising and pedagogical goals. To that aim, the first step was transforming the mission into a brand.

In marketing, a brand is considered an organization's most valuable asset and is defined as an abstract idea used to differentiate a consumer good, a personality, a company, a country, an organization or, as in this case, a project. A brand is the collection of perceptions held by all the people that are aware of the product and the meaning derived from those perspectives [12].

To an organization, a brand is closely tied to its identity, representing who it is, what it believes in, and how it wants to be perceived by its audience [13]. In the case at hand, building a brand meant associating "Colibrí Mission" to the idea that Mexican talent can bring space technology to the world and that being part of a real space mission is possible in Mexico.

According to Forbes, brands can inspire millions of people to join a community and have the power to activate a passionate group of people into action [14]. Organizations large and small have engaged with branding campaigns in the last decades. Considering Colibrí Missions's space project as a brand is an important forward-step in consolidating a space culture in Mexican society.

The process of creating a brand, also known as branding, consists of shaping an organization's image by selecting and mixing tangible and intangible elements in an attractive, meaningful, and compelling way [15]. In a space project, this translates to defining the scientific value (tangible) and the social/cultural impact (intangible) of the whole mission and using them as the key messages in a communication strategy (see Table 1). Branding is the process of researching, developing, and applying a distinctive identity to an organization so that key publics can have something to relate to and connect to [16]. Beyond creating a nanosatellite, Colibrí Mission's branding objectives included creating an identity consisting of a name, a logo, a motto, a team culture, a vision and a social purpose (see Table 2).

Yet branding transcends graphic identity: it makes a project memorable, allows its team members to experience a sense of pride as they built its reputation, and supports marketing and public relations efforts [16]. Colibrí Mission is not the first project that relies on branding for accomplishing its financial and educational objectives.

The desire to make scientific information relatable to the general public was the objective of a campaign organized by the Centers for Disease Control and Prevention (CDC) years ago. Leadership within the CDC spearheaded an identity-building project yielding financial and social gains for the non-partisan organization. "Name awareness" leadership found, was the additional piece allowing the brand "to be the first name that comes to mind (or is recognized on a list of possible organizations) 
when potential donors are considering a donation, which

is very important for building fiscal support" [17, p.18].

Table 1. Tangible and Intangible attributes of Colibrí Mission.

\begin{tabular}{|c|c|}
\hline Tangible attributes & Intangible attributes \\
\hline $\begin{array}{l}\text { The nanosatellite: It will be the first } \\
\text { Mexican 3U CubeSat. }\end{array}$ & $\begin{array}{l}\text { The team: } \\
\text { Its multidisciplinary team consists of undergraduate Mexican students making } \\
\text { technical decisions. }\end{array}$ \\
\hline $\begin{array}{l}\text { The payload: An innovative mechanism } \\
\text { designed specifically for atmospheric } \\
\text { density measurements. }\end{array}$ & The approach: The mission has a scientific rather than a corporate approach. \\
\hline \multirow[t]{4}{*}{$\begin{array}{l}\text { The propulsion: Its nanosatellite uses } \\
\text { electric propulsion, Ion Electrospray } \\
\text { Thrusters, designed by MIT's Space } \\
\text { Propulsion Lab. }\end{array}$} & $\begin{array}{l}\text { Full-cycle engineering: Mexican students lead science, design, build, test and on- } \\
\text { orbit operations. }\end{array}$ \\
\hline & $\begin{array}{l}\text { The socio-economic impact: Thanks to the involvement of international and inter- } \\
\text { institutional advisors, the project boosts the Mexican space sector as it motivates } \\
\text { study and investment in this industry. }\end{array}$ \\
\hline & $\begin{array}{l}\text { The educational impact: At least } 100 \text { students will graduate with their bachelor's } \\
\text { degree having participated in the construction of a real nanosatellite. Their } \\
\text { experience and knowledge are also shared through diverse media content and it will } \\
\text { train a new generation of professionals with experience in satellite development. }\end{array}$ \\
\hline & $\begin{array}{l}\text { The environmental impact: } \\
\text { Its scientific experiment contributes by providing real-time atmospheric density data } \\
\text { to help with the problem of tracking space debris. }\end{array}$ \\
\hline
\end{tabular}

Table 2. Colibrí Mission's brand identity

\begin{tabular}{|l|l|}
\hline Logo & $\begin{array}{l}\text { 1.Hummingbird: In Mexican mythology, the hummingbird is a small } \\
\text { flying animal in charge of the important task of transporting humans' } \\
\text { dreams around the Earth. It's a metaphor about the way a small satellite } \\
\text { can have a big impact on the space industry of a country. } \\
\text { 2. Star: Represents the Universidad Panamericana, as the university that } \\
\text { developed the project. } \\
\text { 3. Star: Represents SPL-MIT, as the institution that directly } \\
\text { collaborates in the project. } \\
\text { 4. Earth: Symbolizes Low Earth Orbit, where the nanosat will operate. } \\
\text { 5. Mexican pattern: symbolizes indigenous Mexican culture. }\end{array}$ \\
\hline Motto & $\begin{array}{l}\text { "Talent in orbit" } \\
\text { Defined by five values: Mexican talent, work ethic, innovation, social } \\
\text { drive and scientific spirit. }\end{array}$ \\
\hline Team Culture &
\end{tabular}

Continuous search for support and sponsorship is a constant concern for the entire Colibrí Mission team. Brand awareness, then, strengthens the relationship with its key stakeholders.

Other campaigns in the United States during the early 2000s brought together social marketing and branding strategies in their efforts to convince those in traditional public relations fields the value of integrating emotional components to a national campaign. The 2002 "Heart
Truth" campaign aimed at increasing awareness among women about the risks of heart disease being a classic example of the emotional value branding can have [18]. Aggregating an emotional dimension in a marketing campaign is not only vital for communicating and generating brand awareness and storytelling, but it is also the way in which a brand can achieve its goal. Stories arouse emotions, and emotions are vital to learning [19]. 
Colibrí Mission has purposefully chosen to use storytelling, as attempts to share the experience of being in a Mexican space mission and relying on the press, social media or other traditional public relations tactics are insufficient.

As brand management scholars claim, a storyteller is usually more authentic, credible, and liked than a person attempting to persuade with facts [20]. Because this project considers Colibrí Mission a brand, it is able to develop a transmedia marketing strategy around it.

\section{Methodology}

After branding, the next step in developing a space project is defining the communication strategy.

Public relations and marketing are the two most common factors of strategic communication. However, other examples exist. Strategic communication refers to intentional communication undertaken by a business or non-profit organization, sometimes by a less structured group, with the purpose of building understanding and support for ideas and causes, brands, services and products, usually in the form of campaigns [21, p.2-3].

Colibrí Mission's Media and Marketing team uses transmedia as a communication tactic and designed a strategic plan for:

a) Public outreach: generating brand awareness

b) Fundraising: managing key specific stakeholders The Media and Marketing team created its own strategic communication plan based on Smith's Strategic Planning for Public Relations Model [21, p.9] which is presented in Table 3.

\subsection{Mapping Stakeholders}

As the third step in the model for building a space project's strategic communication plan suggests (see Table 3), analyzing the public or project's stakeholders is crucial in creating an action plan. A stakeholder is defined as a group or individual that is affected by or has a stake in the project [10, p. 45]. The Stakeholder Expectations Definition Process is the initial step within the Systems Engineering (SE) team, which establishes the foundation from which the mission's system is designed and a product is realized, which is usually in accordance to the customer's expectations [10, p. 46].

However, Colibrí Mission leadership followed other methodology for identifying and understanding the Mission's stakeholders, also called by the SE team as "political" [22] or "non-scientist" [10, p. 46].

One of the most recommended models used in PR for the strategic management of stakeholders is the one proposed by strategy and management professors Colin Eden and Fran Ackermann.
Table 3. Model for building a space project's strategic communication plan

\section{Phase One: Creating the project identity}

Step 1: Generating a project information guide which includes a complete description of the mission: its needs, objectives, scientific, cultural, social and economic impact, work model, expected results and costs

Step 2: Branding: building a project identity including a name, a motto, a logo, a team culture and identifying tangible and intangible attributes

Step 3: Analyzing the public

Phase Two: Strategy

Step 4: Establishing goals and objectives according to the stakeholders

Step 5: Choosing the communications tactics

Step 6: Formulating action strategies

Phase Three: Implementing the strategy

Step 7: Timeline of the mission's life-cycle and communication plan

Phase Four: Evaluating the strategy

Step 8: Analyzing the effectiveness of the plan according to the objectives

Their model consists of generating a generic list of stakeholders and then organizing them into an outline power/interest grid containing four quadrants representing four different stakeholder categories: Crowd, Subjects, Players and Context Setters [23, p.183]. Stakeholders in the upper sides of the grid are those most interested in the project, but with varying degrees of power. For example, those to the right-hand side of the grid have a greater ability to affect the project development but may or may not actually be concerned about its activities. A map of Colibrí Mission's stakeholders is presented in Figure 1.

As explained in the graph, Colibrí Mission's team, including lead advisors and mentors, are labeled as "Players" (PL) because they have the greatest power and interest in the project. By contrast, members of the "Crowd" (CR), with lower power and interest, are considered potential rather than actual stakeholders and are not worthy of management time/effort. 
Figure 1. Colibrí Mission's initial stakeholders

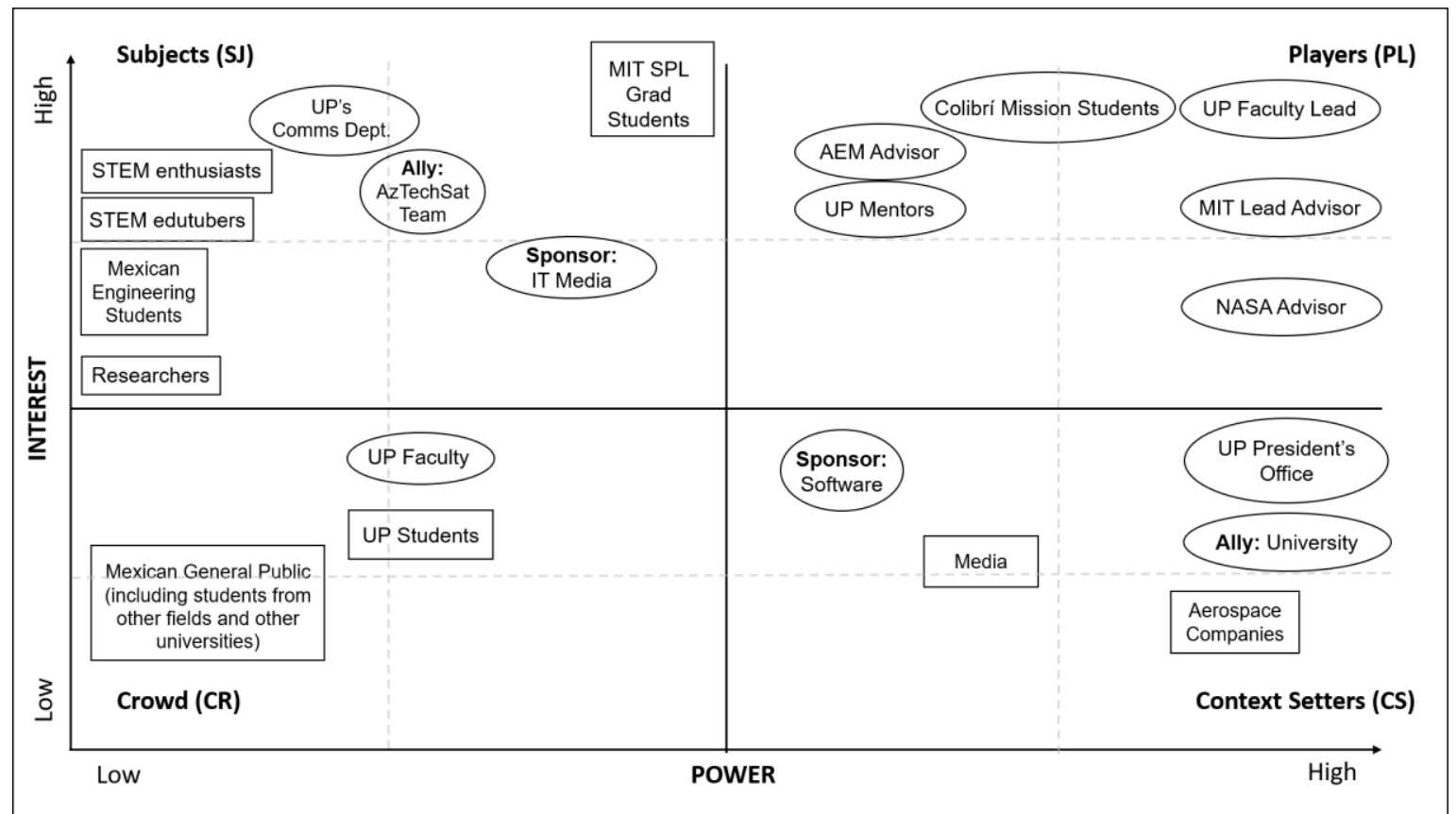

Fig. 1 The names inside the squares represent those with a neutral relation to the project while the ones inside the circles are those with a positive and formal relationship to it.

Subjects (SJ) and Context Setters (CS) are the clues to advance this strategy. With high power but low interest, "Context Setters", such as some aerospace allies, tech sponsors, national media outlets and the UP President's office, can influence the future context. A project, then, should seek to raise awareness and develop interest and convert CS into Players, PL [23, p.183].

However, Colibrí Mission's transmedia strategy helps manage its "Subjects" in order to encourage coalitions that either convert them into Players or push Context Setters into the Players quadrant. As Eden and Ackermann explain, "one stakeholder's actions can generate a dynamic of responses across a range of others [23, p.186].

\subsection{Establishing goals according to the stakeholders}

Taking in account Colibrí Mission's stakeholders' interests (see Appendices A and B), the Media and Marketing Team decided to establish the following objectives:

- Having a positive effect on the action of context setters, specifically for them to trust in the viability and impact of the project in order to encourage them to be sponsors or donors.

- Having a positive effect on the awareness of STEM enthusiasts from the digital community, specifically to increase their understanding of what Colibrí Mission is. This objective implies preparing and sharing the information the team wants their public to be exposed to first and then to know, understand and remember (media channels).

- Having a positive effect on the acceptance of the STEM edu-tubers from the digital community, specifically to gain their interest in sharing what Colibrí Mission represents: advancements in the Mexican space industry. "Acceptance", in this case, is the way people feel about the project and its team, ideas and activities.

\section{Transmedia Theory}

As it built its space project's strategic communication plan, the Colibrí Mission Media and Marketing team decided what it wanted from selected stakeholders. At that juncture it considered what the appropriate communication tactics were to achieve its goals.

The Media and Marketing team chose transmedia due to its multifaceted advantages. [24, p.91] First, it focuses on telling the brand's story, rather than saturating the user with unrelated information. Second, it facilitates the introduction of a new project for those unaware and helps keep them interested. Third, transmedia storytelling contributes to the formation of brand advocates within the audience thanks to the emotional approach of its messages. And lastly, it allows for better organization of the key messages that the brand-project wants to disseminate through various media.

Before detailing its roadmap, Colibrí Mission formulated its own transmedia universe. 
The term transmedia is not new; however, it was formally introduced as "transmedia storytelling" in the $M I T$ Technology Review by media scholar Henry Jenkins [25], and explained further in his book Convergence Culture: "Transmedia storytelling is a story that unfolds across multiple media platforms with each new text making a distinctive and valuable contribution to the whole. In the ideal form of transmedia storytelling, each medium does what it does best (...)" [26, p.95-96].

Jenkins applied the concept of transmedia storytelling to the entertainment industry in what he called "convergence culture": a new way of media consumption where users surf through a flow of information where old media and digital media collide, and in which one platform is not enough to contain a narrative [26].

Integrating transmedia storytelling changes the way audiences interact with entertainment franchises. One way to understand this is through the metaphor of a puzzle. In a puzzle, each piece is a medium that contains a part of the story, enjoyable and understandable by itself. Moreover, each puzzle piece offers the user a complete experience that will be more enjoyable than watching the same tale on different screens.

A few examples of what Jenkins understands as transmedia storytelling are the narrative universes used in Hollywood blockbusters such as The Matrix, The Star Wars sagas, The Blair Witch Project and The Harry Potter series.

However, as narratology theorist Christy Dena warns "transmedia is a term that exists in many research areas but to describe different phenomena". Thus, Dena proposes simplifying the wide range of creative applications and implementing the term "transmedia practices" instead [27, p.16].

Gradually, transmedia storytelling is being adopted by scholars in the strategic communications field. For instance, marketing professor J. Cronin points out that "evidence of the increasing adoption of transmedia includes the appearance of advertising and marketing agencies that offer transmedia storytelling or brand story support [24, p.89]."

Despite the fact that corporate or business applications of transmedia storytelling are relatively new, a number of authors have already produced relevant academic research.

For example, noted European communications scholar Carlos A. Scolari coined the concept "brand-worlds" to better explain the connection between transmedia storytelling and branding. "Brand-worlds" refers to the production of contents aligned to key messages that help link a brand with values, characters, and ideals [28].

Another scholar who has provided noteworthy contributions is the business transmedia consultant Robert Pratten who gave a twist to Jenkins' transmedia definition by adding an emotional dimension to the mediatic experience. "Transmedia is also taking the audience on an emotional journey that goes from moment-to-moment," he writes [29, p.14]. In his work, Pratten highlights the difference between transmedia storytelling and multiplatform storytelling, explaining that the former attempts to create synergy between the content while the latter may disregard the emotional factor.

It is important to emphasize what Pratten considers vital for a marketing application of transmedia: that the creative team should remember to generate content that meets the personal and social needs of the target audience so that the target audience can easily connect with the brand and share it in their networks [29, p.17].

As a guide, Colibrí Mission's Media and Marketing unit adhered to the transmedia definition proposed by professor Cronin: "a process whereby elements of a brand story get dispersed systematically across multiple media for the purpose of creating a unified and coordinated consumer experience with the brand, with each medium making its own unique contribution to the unfolding of the story [29, p.89]".

\subsection{Advantages of using Transmedia for Public Outreach in a Space Project}

Branding the space project provides a basis in which the mission can communicate values and add people to a cause, also enriching the way its scientific value is explained to the public, as explained in section 1.3 Communicating Colibrí Mission as a Brand.

One of the traditional ways a space project could be disseminated to the general public (the non-specialized public) is through an integrated marketing communication strategy (IMC). This approach suggests choosing a series of communication channels, owned or gained by the project, and ensuring that there is unified content distributed through them and that the organization's key messages are conveyed [24, p.86]. This way whoever the user may be and whatever kind of content he/she/they consult, they will be able to find the same discourse in all channels. However, transmedia storytelling is not integrated marketing.

Some projects might decide to launch social media accounts, create a website or perhaps even a YouTube channel for a project. Colibrí Mission, however, seeks not only to share content but immerse its followers in a different experience: it is no longer about repeating what is done over multiple media platforms, but sharing fresh content through different media channels about how a Mexican space mission is developed.

Compared to other traditional marketing approaches, "transmedia allows brands a larger canvas in which to tell their story by leveraging the best features in each platform to enhance every piece of the experience; giving diversity and richness to the content and characters and helping users get the most out of a great story [12]". 
Colibrí Mission's Media and Marketing team chose transmedia as its communication tactic in order to better accomplish the objective of sharing to STEM publics (enthusiasts and edu-tubers) and other subjects the experience of belonging to a Mexican space mission.

Table 4 includes a list of characteristics and reminders that could be used in preparation for a transmedia communication strategy. More information can be found in Jenkins and Pratten [26] [29].

Table 4. Characteristics and reminders for building a transmedia communication strategy

\begin{tabular}{|c|c|}
\hline $\begin{array}{c}\text { Transmedia } \\
\text { Characteristics }\end{array}$ & $\begin{array}{c}\text { Reminders in } \\
\text { Adopting/Using }\end{array}$ \\
\hline $\begin{array}{l}\text { 1. Unfolds the brand story } \\
\text { across multiple media } \\
\text { platforms. } \\
\text { 2. Each new channel } \\
\text { makes a distinctive and } \\
\text { valuable contribution } \\
\text { to the whole but exists } \\
\text { consistency between } \\
\text { the content. } \\
\text { 3. Each medium does } \\
\text { what it does best. } \\
\text { 4. Each content needs to } \\
\text { be self-contained is a } \\
\text { point of entry to the } \\
\text { whole. } \\
\text { 5. Depth of experience } \\
\text { motivates more } \\
\text { consumption: making a } \\
\text { list of related topics to } \\
\text { the project is helpful. } \\
\text { 6. Different media } \\
\text { attracts different } \\
\text { marketing niches. }\end{array}$ & $\begin{array}{l}\text { 1. It should preferably be } \\
\text { planned from the } \\
\text { beginning of the project. } \\
\text { 2. A single team or creative } \\
\text { unit should conceive the } \\
\text { transmedia universe. } \\
\text { 3. Some users have become } \\
\text { prosumers, so they can } \\
\text { co-create or help expand } \\
\text { the transmedia universe, } \\
\text { but the team can also } \\
\text { invite collaborators to } \\
\text { join. } \\
\text { 4. Together with a call to } \\
\text { action, make the user } \\
\text { search for more. } \\
\text { 5. Answering the basic W } \\
\text { questions helps in the } \\
\text { decision of how to } \\
\text { distribute content. } \\
\text { 6. Each channel may have } \\
\text { its own name. }\end{array}$ \\
\hline
\end{tabular}

To summarize, for a project with this level of scope, using transmedia in the communication strategy implies choosing and opening selected media channels, according to the key stakeholders and planning what the project is going to tell or share in each one of them. This plan should happen from the beginning of the project. Finally, the content must offer a complete experience of what the brand is.

\subsection{Colibrí Mission's Transmedia Universe}

According to the sixth step in the model described in section 2 Methodology, Colibrí Mission followed this roadmap as it built its own transmedia universe:

First, it was necessary to decide which communication channels could be addressed and in which order they would be activated in a feasible way. In order to do so, the Media and Marketing team adapted the Priority Worksheet commonly used in PR to identify which stakeholders each of the communication channels targeted (see Appendix C) [21, p.52]. The platforms which are able to bring together the largest number of key publics were the first to open.

Appendix D describes the platforms, channels or "branches" in Colibrí Mission's transmedia universe and presents a tagline or message for its stakeholders' objectives.

After building Colibrí Mission's transmedia universe structure, the Media and Marketing team created a timeline in which they transposed each of the transmedia branches to the technical life-cycle of the mission. This way the team was able to organize a work plan that followed the guidelines of Appendix C (Priority Worksheet) and one which can adjust to the availability and depth of the content the Colibrí team acquires as it advances.

The final step was implementing the strategy and analyzing the effectiveness of each transmedia channel on average every three months.

\section{Results}

When this paper was being drafted, Colibrí Mission was in the midst of completing the Critical Design Review (CDR). This technical phase, as the timeline in Appendix E explains, takes place in conjunction with the release of three strategic channels: a website, social media accounts, and a blog. This analysis includes the dates between May 5, 2019 and August 27, 2020. A complete description of the metrics used is found in Appendix F.

\subsection{Website}

Since its creation on May 5, 2019, Colibrí Mission's website has accumulated 3,680 page views with $39 \%$ returning visitors and $61 \%$ new visitors, as shown in Figure 2 and Figure 3. Blog posts have also increased in viewership (76\%) in contrast to the first post which had 224 views. As Figure 2 suggests, there is a significant increase in website traffic in relation to the number of blog posts.

The data reveals that almost half of website traffic comes directly from entering the web address on the browser, which indicates high brand recognition amongst followers (see Figure 4). One third of the website traffic enters through a search engine, while a small percentage comes from Facebook and a very small percentage is generated from other websites or social media platforms.

\subsection{Social Media}

Over 15 months, Colibrí Mission's Facebook likes have increased ten times, jumping from 100 to more than 1,100 . Figure 5 shows a clear correlation between likes and the creation of the blog and its four published posts, marked in orange triangles. In the last two months, the site added 385 likes, increasing its fan base by $52 \%$. 
Moreover, the Facebook page gained followers after important press events: media coverage from national media outlets such as TV Azteca, Efekto TV, Heraldo and an edu-tuber event covering the "NASA Rover Mars 2020 Launch" via Youtube Live. These events are displayed with blue diamonds in Figure 5.

Facebook weekly engagement peaks also correlate with important media events. For example, the page's biggest peak corresponds to the team's PDR at MIT during the summer of 2019, while its second biggest value corresponds to the blog creation. These same correlations are revealed in the Facebook Weekly Total Reach data, presented in Figure 6.

AzTechSat-1's launch had a direct effect on Colibrí Mission's Facebook engagement on the day of the launch, February 19, 2020. This key date corresponds to the fourth highest number in Figure 6.

As Figure 7 shows, since their creation, the Twitter and Instagram accounts have grown in a linear fashion. Colibrí Mission has had more Instagram than Twitter activity during the time period under analysis. The Instagram account began with a healthy initial community and has potential to increase because each post generates a $16 \%$ average engagement. Colibrí Mission's Twitter account is the most recent live channel and will need to be evaluated in a future study.

Furthermore, on average, $28 \%$ of the Mission's followers indicated some sort of STEM interest on their profiles, either by liking STEM-related sites, having completed university studies in a STEM field or by explicitly indicating their interest on their bios. The distribution of STEM followers by platform is shown in Figure 8.

Figure 2. Website Page Views

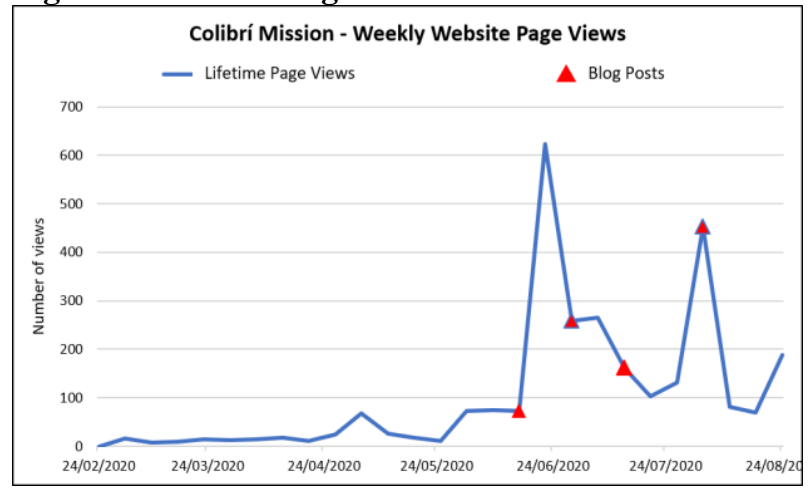

Figure 3. Website Visitor Type

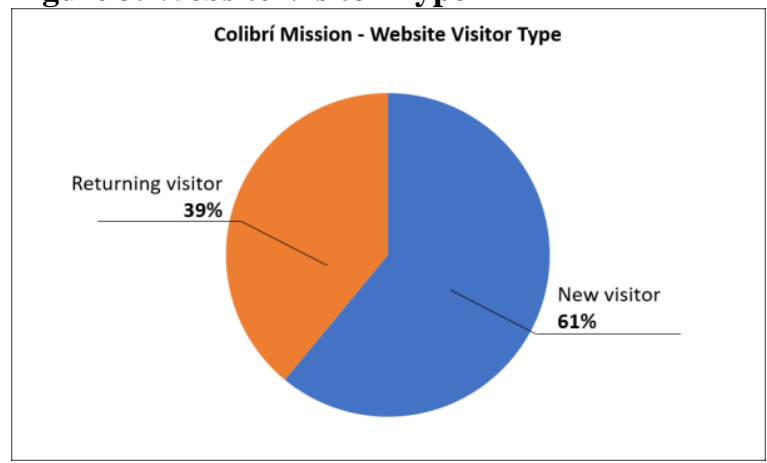

Figure 4. Website Traffic Source

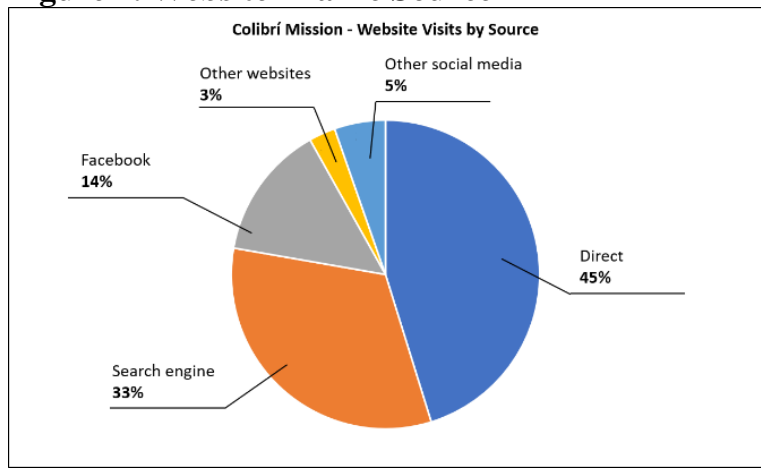

Figure 5. Facebook Lifetime of total likes

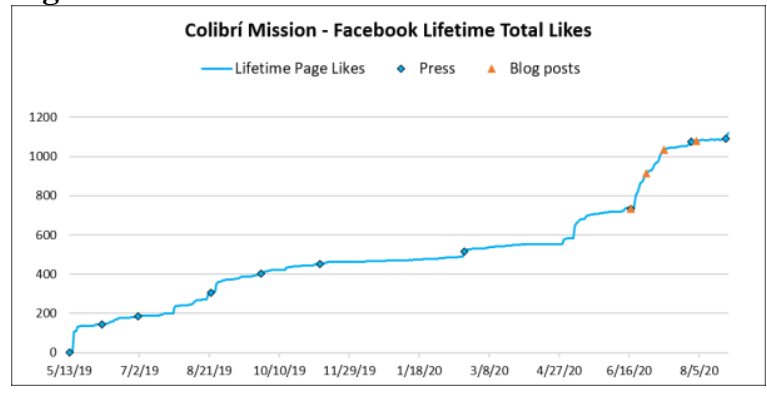

Figure 6. Facebook Weekly Engagement

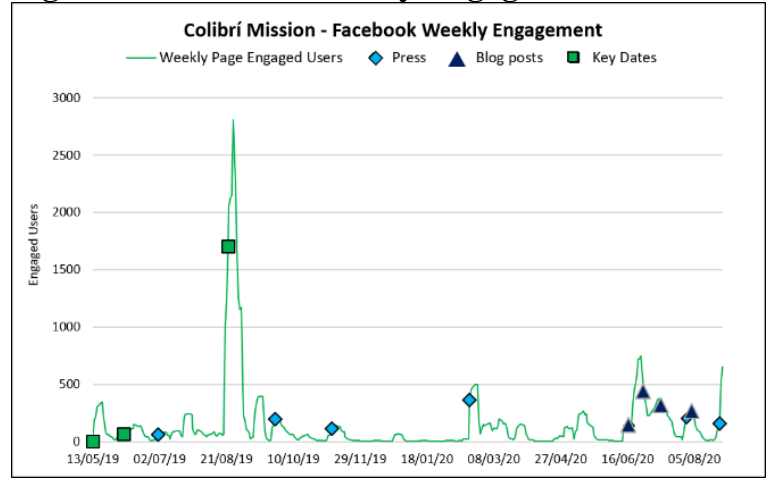




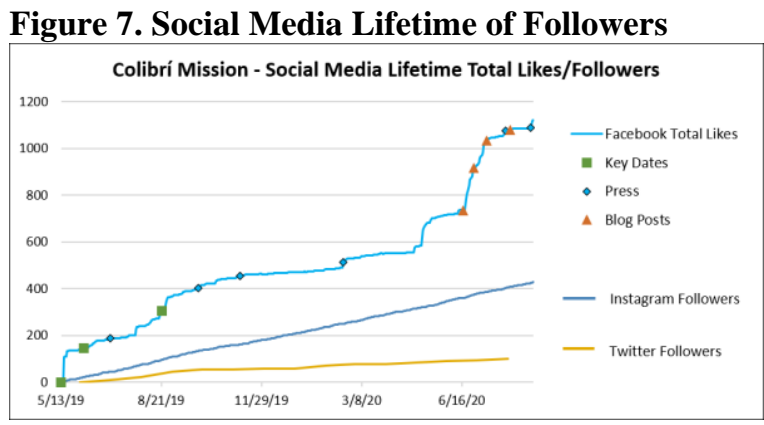

Figure 8. STEM followers

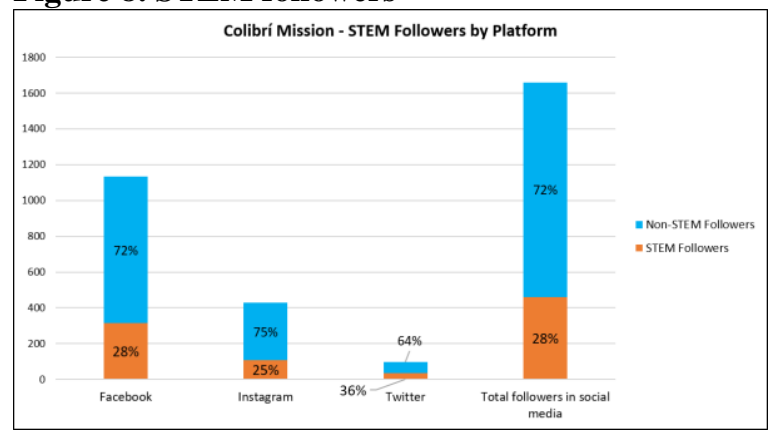

\section{Discussion}

An analysis of the previous metrics offers the following insights:

Colibrí Mission's website has been able to attract the attention of the public organically and thanks to its blog, visitor's attention has been maintained while new user traffic has simultaneously increased. (see Figures 2 and 3 ). The number of visits is in direct correlation to a direct search for "Colibrí Mission" on the internet, which suggests brand recognition and potential positioning of its users. Furthermore, the fact that social media accounts redirect users to visit the website reveals an interest in navigating and knowing Colibrí Mission's universe better (see Figure 4).

The blog's readers increase after each post, which suggests growing interest in the published themes (see section 4.1). This interest has the potential to increase if the other transmedia branches in the strategy are followed (see Appendices D and E).

Since the first phase of the strategy, the combination of transmedia and public relations tactics, such as being interviewed by the national press, have contributed to an increase in the community of followers on social media and their engagement with Colibrí Mission (see Figures 5 and 6 ).

More than one quarter of Colibrí Mission's followers on social media are interested in STEM fields, which indicates that the strategy has been able to connect with people in the general public and specialized one.

Colibrí Mission's team affirms that the initial objectives of the transmedia strategy set out in section 2.2 were accomplished. One very important insight in the use of this strategy was the improvement of relationships with certain stakeholders and the acquisition of new allies as shown in Figure 9.

Some of the new allies the project has gained so far include: one tech sponsor, a space company, two external volunteer mentors and one sponsor of social media content. Previously unknown to the team, each ally showed their interest in the project via Facebook and the website. Colibrí Mission attributes their willingness to collaborate to an increase in social media followers and outreach, combined with their own interest in the space industry.

Adding a sponsor company and external mentors to the project is important, as specialized experience in the space field is often a make or break condition in university space projects (read more in [30]), and because it increases the possibility of obtaining external funding: "Many academic teams benefited from experienced leads and mentors (...), it appears that the more experienced the mentor, the greater the success rate among academic institutions. Successful teams consulted knowledgeable peers either inside or outside their organization" [30].

Additionally, the community of STEM enthusiasts and STEM edu-tubers also moved: STEM edu-tubers showed an increase in interest and power to communicate the project after a Youtube live event. Live comments during the event showed good acceptance from the audience.

The new social media sponsor offered to create attractive and interactive posts that now contribute to expand the information about Colibrí Mission available in social media. UP's institutional communications office increased its interest in sharing content and posts generated by the Media and Marketing team in UP's social media sites. This increases the notoriety of the project as a whole, inside and outside of UP's digital community. Colibrí Mission's team was also able to increase its social media followers by sharing curated content to improve understanding of what the mission entails technically.

Furthermore, the team achieved its goal of influencing its Context Setters thanks to the initial transmedia activities and adjusted its interest and power to better suit the project's needs. Mainly, thanks to the increase in notoriety due to media activities, the President of the UP took notice of Colibrí Mission and substantially increased his involvement in it. Due to this change, the President's office is now leading the fundraising campaign in contrast to having the faculty lead as before. This change caused the President of the UP to move from Context Setter to Key Player.

Similarly, the tech sponsor increased its interest and involvement in the project and became a Key Player, taking a more active role in mentorship. Finally, Media outlets showed more interest to talk about the project on their platforms, increasing the project's outreach. 
Figure 9. Colibrí Mission's new stakeholders

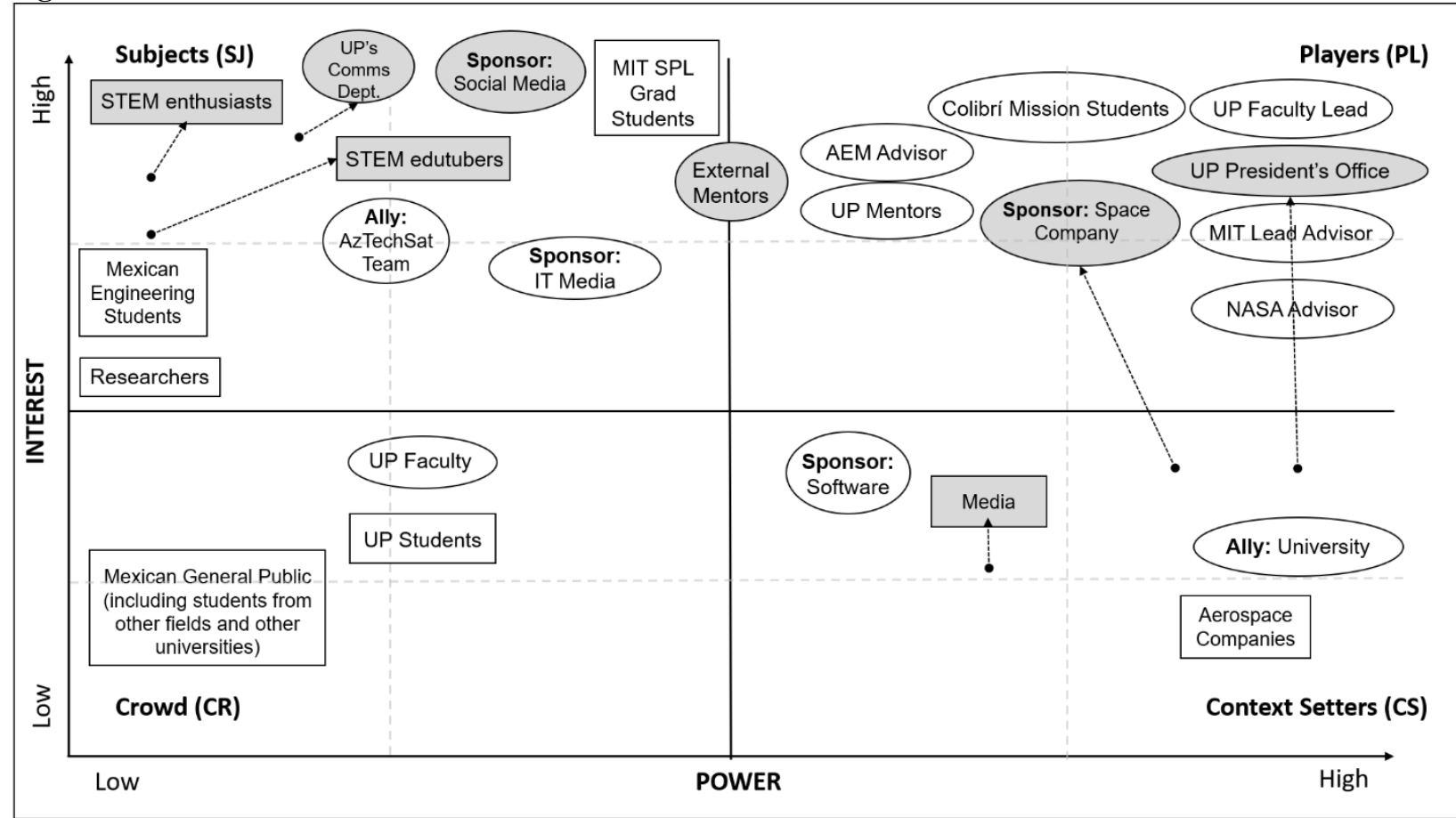

Fig. 9 The shaded names in the graph are those who moved within the power/interest grid. The arrows indicate their initial and final position. (Names have been changed to protect confidentiality).

\section{Conclusions}

As the creator of one of the first Mexican nanosatellites, Colibrí Mission has distinctive attributes that will allow it to offer its own legacy, which combines the strengths of two disciplines: engineering and communication.

Its scientific objectives are designing and building a $3 \mathrm{U}$ CubeSat that will prove new space technology, measure atmospheric density at Low-Earth Orbit (LEO) and contribute to the mitigation efforts of space debris. The undergraduate students in the team seek to go further: Colibrí Mission aims to develop the Mexican space industry and inspire and train a new generation of professionals in satellite development. A Media and Marketing unit was created in Colibrí Mission for this reason. The team is focused on developing communication strategies and fundraising campaigns to increase the development of the project. Taking into account the financial constraints confronted by a university space project, the Media and Marketing team developed a communication plan which allowed it to generate brand awareness and manage key specific stakeholders.

Adapting a public relations model and utilizing the methodology proposed by Colin Eden and Fran Ackermann to map stakeholders, Colibrí Mission's strategy sought to influence key stakeholders to better suit the Mission's needs and transmit the experience of what it means to belong to a Mexican space mission.
Instead of falling back on traditional PR and IMC strategies, the team chose transmedia due to its multifaceted advantages. First, it focuses on telling the brand's story, rather than saturating the user with unrelated information. Second, it facilitates the introduction of a new project for those unaware and helps keep them interested. Third, transmedia storytelling contributes to the formation of brand advocates within the audience thanks to the emotional approach of its messages. And lastly, it allows for better organization of the key messages that the brandproject wants to disseminate through various media.

Generally, not all key stakeholders participate in every transmedia channel, but this can be a tactic giving you greater visibility. In this case, we realized that by focusing on subjects we were able to indirectly shift Context Setters to key players, which helped Colibrí Mission obtain greater institutional support from the University President, increased the interest of the sponsor space company and obtained new external mentors with experience in the space sector.

Public outreach has been taken into account as an important factor in the development of the whole Mission since its initial stages, because it provides other advantages. Finally, it echoes Colibrí Mission's outreach vision: "To transcend frontiers does not only mean going through layers of the atmosphere, it also means to transcend in time. We will achieve so by educating and mentoring the generations to come, 
which will certainly accomplish greater goals by the work we are carrying out today."

\section{Acknowledgements}

This paper is part of a video lecture and paper presented at the 71st International Astronautical
Congress, CyberSpace Edition, October 12 - 14, 2020, IAC-20-E1.6.5 $\times 59480$. The authors would like to thank all the people involved in the development of Colibrí Mission, specially to the Media and Marketing members. 
$71^{\text {st }}$ International Astronautical Congress (IAC) - The CyberSpace Edition, 12-14 October 2020.

Copyright $@ 2020$ by the International Astronautical Federation (IAF). All rights reserved.

\section{Appendix A - Description of internal and external Colibrí Mission's stakeholders}

\begin{tabular}{|c|c|}
\hline STAKEHOLDER & DESCRIPTION \\
\hline Colibrí Mission Students & UP Students that are part of Colibrí Mission and actively participate in the team's activities. \\
\hline UP Faculty Lead & Deans of engineering at both campuses and project faculty leader of Colibrí Mission. \\
\hline MIT Lead Advisor & Lead advisor from MIT. \\
\hline AEM Advisor & Mexican Space Agency advisor. \\
\hline NASA Advisor & NASA advisor \\
\hline UP Mentors & UP faculty that serve as mentors for students. \\
\hline External Mentors & $\begin{array}{l}\text { People outside of UP that volunteer their time to mentor students in the technical aspects of } \\
\text { the project. }\end{array}$ \\
\hline University President's office & Office of the president that oversees all UP campuses \\
\hline Sponsor: space company & Allied space company based in Spain with an UP alumni CEO and founder. \\
\hline Sponsor: IT media & $\begin{array}{l}\text { Media sponsor and donor of the project that is a media outlet for the Information } \\
\text { Technologies field with a focus to industry applications. }\end{array}$ \\
\hline Sponsor: Social Media & Sponsor of the project that helps create social media content. \\
\hline Sponsor: Software & Software company that provided free education licenses for the project. \\
\hline Ally: University & Allied University in Mexico with specialized facilities and experience in the space sector. \\
\hline Ally: AztechSat-1 & Allied University project that launched the first Mexican $1 \mathrm{U}$ CubeSat \\
\hline MIT SPL Graduate Students & Graduate Students of MIT’s Space Propulsion Laboratory (SPL) \\
\hline $\begin{array}{l}\text { UP's Communication } \\
\text { Department }\end{array}$ & It manages the internal and external communication strategies. \\
\hline STEM Edu-tubers & $\begin{array}{l}\text { Youtubers dedicated to the communication of educational videos related to scientific and } \\
\text { engineering fields. }\end{array}$ \\
\hline STEM Enthusiasts & General public that is interested in STEM fields. \\
\hline Media & Mexican communication outlets. \\
\hline Aerospace Companies & Foregin and national companies related to the aerospace industry. \\
\hline $\begin{array}{l}\text { Mexican Engineering } \\
\text { Students }\end{array}$ & $\begin{array}{l}\text { Mexican engineering students of the general public who could participate in a similar } \\
\text { project. }\end{array}$ \\
\hline Researchers & Researchers in STEM fields. \\
\hline UP Students and UP Faculty & General student population at UP / General faculty population of UP \\
\hline Mexican General Public & $\begin{array}{l}\text { General Mexican population that could receive information on the project includes high- } \\
\text { school and university students, not necessarily from STEM fields, from the Mexican } \\
\text { general population. }\end{array}$ \\
\hline
\end{tabular}


$71^{\text {st }}$ International Astronautical Congress (IAC) - The CyberSpace Edition, 12-14 October 2020.

Copyright $\odot 2020$ by the International Astronautical Federation (IAF). All rights reserved.

Appendix B - Matrix of interests of Colibrí Mission's stakeholders

\begin{tabular}{|c|c|c|c|c|}
\hline STAKEHOLDER & Financial & Academic & Professional & Reputational \\
\hline Colibrí Mission Students & & $\mathrm{X}$ & $X$ & \\
\hline UP Faculty Lead & & $\mathrm{X}$ & $\mathrm{X}$ & $\mathrm{X}$ \\
\hline MIT Lead Advisor & $\mathrm{X}$ & $\mathrm{X}$ & & \\
\hline AEM Advisor & & $\mathrm{X}$ & & $\mathrm{X}$ \\
\hline NASA Advisor & & $\mathrm{X}$ & & \\
\hline UP Mentors & & $\mathrm{X}$ & & $\mathrm{X}$ \\
\hline External Mentors & & $X$ & $\mathrm{X}$ & $\mathrm{X}$ \\
\hline University President's office & $\mathrm{X}$ & $\mathrm{X}$ & & $\mathrm{X}$ \\
\hline Sponsor: space company & $X$ & & & \\
\hline Sponsor: IT media & & & & $\mathrm{X}$ \\
\hline Sponsor: Social Media & & & $\mathrm{X}$ & $\mathrm{X}$ \\
\hline Sponsor: Software & $\mathrm{X}$ & & & \\
\hline Ally: University & & $\mathrm{X}$ & $X$ & $\mathrm{X}$ \\
\hline Ally: AztechSat-1 & & $\mathrm{X}$ & $\mathrm{X}$ & $\mathrm{X}$ \\
\hline MIT SPL Graduate Students & & $\mathrm{X}$ & $\mathrm{X}$ & \\
\hline UP's Communications Department & & & & $\mathrm{X}$ \\
\hline STEM Edu-tubers & & $\mathrm{X}$ & & $\mathrm{X}$ \\
\hline STEM Enthusiasts & & $\mathrm{X}$ & & \\
\hline Media & & & & $\mathrm{X}$ \\
\hline Aerospace Companies & $\mathrm{X}$ & & & $\mathrm{X}$ \\
\hline Mexican Engineering Students & & $\mathrm{X}$ & & \\
\hline Researchers & & $\mathrm{X}$ & $\mathrm{X}$ & \\
\hline UP Students & & $\mathrm{X}$ & & $\mathrm{X}$ \\
\hline UP Faculty & & $\mathrm{X}$ & & $\mathrm{X}$ \\
\hline Mexican General Public & & $\mathrm{X}$ & & \\
\hline
\end{tabular}




\section{Appendix C - Priority Worksheet}

\begin{tabular}{|l|c|c|c|c|c|c|c|c|}
\hline Subjects: stakeholders & WS & FB & IG & Twt & Blog & Vlog & Podcast & App \\
\hline Researchers & X & X & & X & X & & X & \\
\hline UP Communications Department & $\mathrm{X}$ & $\mathrm{X}$ & $\mathrm{X}$ & & & & & \\
\hline STEM edutubers & & $\mathrm{X}$ & $\mathrm{X}$ & & & $\mathrm{X}$ & & \\
\hline STEM enthusiasts & $\mathrm{X}$ & $\mathrm{X}$ & $\mathrm{X}$ & & $\mathrm{X}$ & $\mathrm{X}$ & $\mathrm{X}$ & $\mathrm{X}$ \\
\hline Mexican engineering students & $\mathrm{X}$ & $\mathrm{X}$ & $\mathrm{X}$ & & $\mathrm{X}$ & $\mathrm{X}$ & $\mathrm{X}$ & $\mathrm{X}$ \\
\hline MIT SPL Grad students & $\mathrm{X}$ & $\mathrm{X}$ & $\mathrm{X}$ & $\mathrm{X}$ & & & & \\
\hline TOTAL NUMBER OF PUBLICS & $\mathbf{5}$ & $\mathbf{6}$ & $\mathbf{5}$ & $\mathbf{2}$ & $\mathbf{3}$ & $\mathbf{3}$ & $\mathbf{3}$ & $\mathbf{2}$ \\
\hline
\end{tabular}


$71^{\text {st }}$ International Astronautical Congress (IAC) - The CyberSpace Edition, 12-14 October 2020.

Copyright @2020 by the International Astronautical Federation (IAF). All rights reserved.

Appendix D - Colibrí Mission's transmedia universe

\begin{tabular}{|c|c|c|}
\hline Platform & Content & Objective \\
\hline $\begin{array}{l}\text { 1.Website } \\
\text { (WS) }\end{array}$ & $\begin{array}{l}\text { A website is a basic channel for a project to communicate with the public who are actively } \\
\text { seeking information, whether it's a site hosted on the home page of the institution or } \\
\text { university that supports the project or separately. } \\
\text { Colibrí Mission's website is designed principally to give a glimpse of the project's team } \\
\text { structure and objectives. It offers a formal contact entry, a complete description of the } \\
\text { students in the team and collects press appearances. }\end{array}$ & $\begin{array}{l}\text { "Tell who we are to the } \\
\text { general public" }\end{array}$ \\
\hline $\begin{array}{l}\text { 2. Facebook } \\
\text { Fan Page } \\
\text { (FB) }\end{array}$ & $\begin{array}{l}\text { This is the central social media account: it includes posts of important last minute goings on } \\
\text { of the project. It is focused on generating a community aware of Colibrí Mission in general. }\end{array}$ & $\begin{array}{l}\text { "Tell who we are to } \\
\text { STEM enthusiasts." }\end{array}$ \\
\hline $\begin{array}{l}\text { 3. } \\
\text { Instagram } \\
\text { Account } \\
\text { (IG) }\end{array}$ & $\begin{array}{l}\text { Is the visual social media account: posts include photos, infographics and behind-the-scenes } \\
\text { content related to the development of the nanosatellite. It offers fresh and bilingual } \\
\text { information about the students working inside labs as it is focused on international instagram } \\
\text { users. }\end{array}$ & $\begin{array}{l}\text { "Show how we work } \\
\text { to the STEM } \\
\text { international } \\
\text { community" }\end{array}$ \\
\hline $\begin{array}{l}\text { 4. Twitter } \\
\text { Account } \\
\text { (Twt) }\end{array}$ & $\begin{array}{l}\text { This social media account appeals to the concept of "subjectivity", a transmedia principle } \\
\text { proposed by Jenkins [*p.9], which refers to generating content that relates the project from } \\
\text { a different point of view that comes from some character belonging to the universe. } \\
\text { For example, in Colibrí Mission's twitter account, a student member of the team tweets what } \\
\text { is like to be an undergraduate student and a young scientist who builds a nanosatellite in } \\
\text { Mexico, so followers can imagine the challenges, the homework, the funny things and the } \\
\text { other side of a space mission. }\end{array}$ & $\begin{array}{l}\text { "Tell professors, } \\
\text { students and } \\
\text { international } \\
\text { community how it is to } \\
\text { be a Mexican } \\
\text { undergraduate student } \\
\text { who belongs to a space } \\
\text { mission" }\end{array}$ \\
\hline 5. Blog & $\begin{array}{l}\text { Titled "Bitácora Espacial", which means Space Log, this blog speaks to a public who wants } \\
\text { to understand what it means to develop a space mission in Mexico, including the internal } \\
\text { functions of each subsystem. }\end{array}$ & $\begin{array}{l}\text { "Explain how a } \\
\text { Mexican space } \\
\text { mission is organized to } \\
\text { STEM enthusiasts" }\end{array}$ \\
\hline $\begin{array}{l}\text { 6.Vlog } \\
\text { (videoblog) }\end{array}$ & $\begin{array}{l}\text { A YouTube channel where students can learn about the science of building a CubeSat } \\
\text { through brief tutorials and lectures. }\end{array}$ & $\begin{array}{l}\text { "Explain how to build } \\
\text { a Cubesat to STEM } \\
\text { professionals and } \\
\text { students" }\end{array}$ \\
\hline 7.Podcast & $\begin{array}{l}\text { This series of audio episodes contain brief interviews and talks where our advisors and } \\
\text { sponsors share their space experiences, opinion about space industry news and knowledge } \\
\text { related to different fields: from aerospace engineering to communication. }\end{array}$ & $\begin{array}{lr}\text { "Connect our } & \text { team } \\
\text { with } & \text { STEM } \\
\text { professionals } & \text { and } \\
\text { students". } & \end{array}$ \\
\hline 8. App & $\begin{array}{l}\text { A Virtual Reality app is being designed by the engineering students from the team. This app } \\
\text { allows users who have an IOS or Android mobile phone to interact with our nanosat and } \\
\text { understand its structure. }\end{array}$ & $\begin{array}{l}\text { "Let the general public } \\
\text { interact with our } \\
\text { nanosatellite" }\end{array}$ \\
\hline $\begin{array}{l}\text { 9. } \\
\text { Conferences } \\
\text { and talks }\end{array}$ & $\begin{array}{l}\text { Although these are not digital media channels, the academic nature of the project implies } \\
\text { presenting scientific advancements in conferences and talks which expand the universe by } \\
\text { sharing information about the nanosatellite in a more technical way. }\end{array}$ & $\begin{array}{l}\text { STEM researchers, } \\
\text { professors and } \\
\text { students. }\end{array}$ \\
\hline 10. Press & $\begin{array}{l}\text { Even though news media is partially uncontrolled, it offers the possibility to reach larger } \\
\text { audiences for free and adds credibility to the project's technical and social objectives. That } \\
\text { is why Colibrí Mission has also considered developing specific material for a press kit, such } \\
\text { as a brochure, a project video and some unique animations and renders of its nanosatellite. }\end{array}$ & $\begin{array}{l}\text { National press and } \\
\text { digital media }\end{array}$ \\
\hline $\begin{array}{l}\text { 11. Special } \\
\text { Events }\end{array}$ & $\begin{array}{l}\text { Occasionally, Colibrí Mission has considered organizing fundraising events that include the } \\
\text { interaction with possible donors. Talking about transmedia, these events add to the universe } \\
\text { by offering distinctive material such as a "ticket to the orbit" which gives donors the reward } \\
\text { of sending their name to space through our nanosatellite. }\end{array}$ & Donors \\
\hline
\end{tabular}




\section{Appendix E - Transmedia timeline}

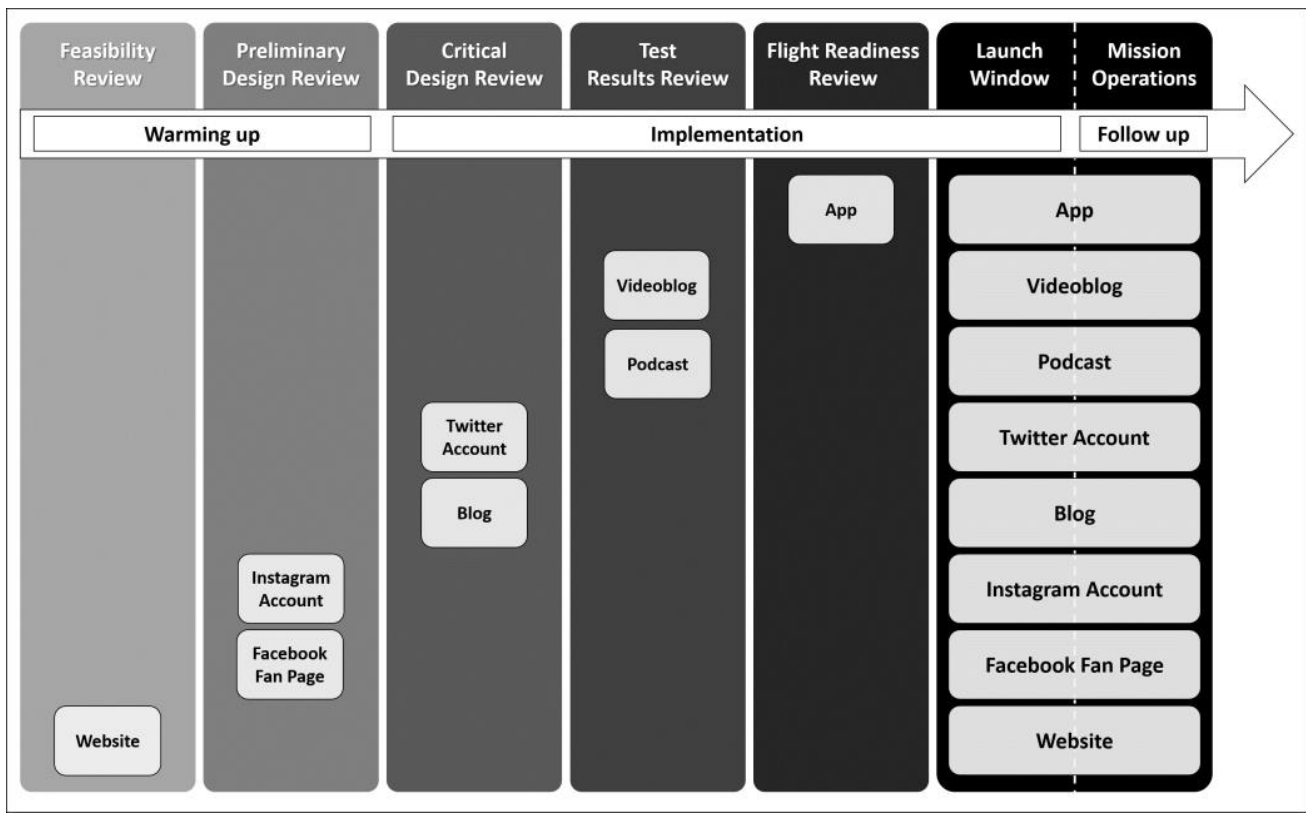

Appendix F - Metrics and Key dates

\begin{tabular}{|l|l|}
\hline Key date & Description \\
\hline May 5, 2019 & Colibrí Mission's website was published \\
\hline May 13, 2019 & Colibrí Mission's Facebook and Instagram accounts opened \\
\hline June 21, 2019 & Colibrí Mission's Twitter account opened \\
\hline August 22, 2019 & Colibrí Mission presented its Preliminary Design Review \\
\hline June 17, 2020 & Colibrí Mission's blog was published \\
\hline
\end{tabular}

\begin{tabular}{|c|c|}
\hline Metric & Description \\
\hline $\begin{array}{l}\text { Likes / } \\
\text { Followers }\end{array}$ & Refers to the total number of people who have liked the page/account. \\
\hline Reach & $\begin{array}{l}\text { Refers to the number of unique users who had any content of the page/account enter their feed, which includes posts } \\
\text { and any social information from people who interact with the page/account. }\end{array}$ \\
\hline Page Views & Refers to the number of visits to the website, including new and returning visitors. \\
\hline $\begin{array}{l}\text { STEM } \\
\text { users }\end{array}$ & $\begin{array}{l}\text { Refers to followers containing one or more of the following characteristics: having studied a STEM career in an } \\
\text { official institution; explicitly stating in their profile their affinity with STEM fields; official pages diffusing STEM } \\
\text { science; or that the sociodigital platform recognizes that their general interests, in correlation to their consumption, } \\
\text { are tagged under "science, technology and engineering" or "aerospace business." *Note: this tally was realized } \\
\text { thanks to the tools provided by the social media platforms and only includes users with a public profile. }\end{array}$ \\
\hline
\end{tabular}




\section{References}

[1] AEM, "Antecedentes de la AEM", Gobierno de México, 2011, https://www.gob.mx/aem/acciones-yprogramas/antecedentes-de-la-aem, (accessed 30.05.20)

[2] AEM, "¿Qué hacemos?", Gobierno de México, https://www.gob.mx/aem/que-

hacemos\#: :text=Nuestra\%20Visi\%C3\%B3n\%3A,al\% 20crecimiento $\% 20$ econ $\%$ C $3 \%$ B 3 mico $\% 20 \mathrm{de} \% 20 \mathrm{M} \% \mathrm{C}$ 3\%A9xico, (accessed 30.05.20).

[3] Secretaría de Comunicaciones y Transportes, "Acuerdo mediante el cual se dan a conocer las Líneas Generales de la Política Espacial de México”, Diario Oficial de la Federación, Estados Unidos Mexicanos, July 3, 2011, http://sidof.segob.gob.mx/notas/5200730, (accessed 30.05.20).

[4] AEM, "Plan de Órbita 2.0", ProMéxico, Ciudad de México, 2017, pp. 10-34

[5] G. Lugo, "El satélite universitario UAMSAT-B fue puesto en órbita", Gaceta UNAM, September 9, 1996, pp. 3-4,

https://www.dint.unam.mx/blog/index.php/item/3201el-satelite-universitario-uamsat-b-fue-puestoexitosamente-en-orbita, (accessed 02.06.20).

[6] NASA, "What is AzTechSat-1?", 2020, https://www.nasa.gov/ames/aztechsat-1, (accessed 03.06.20).

[7] UPAEP - AzTechSat-1, 2020, https://upaep.mx/aztechsat, (accessed 03.06.20).

[8] Secretaría de Economía, PROMÉXICO, FEMIA, "Conociendo la Industria aeroespacial", INEGI, Aguascalientes, México, 2016, p23.

[9] AEM, "A 10 Años De Su Creación, La AEM Ha Puesto A México En El Concierto Mundial Del Desarrollo Científico Y Tecnológico", Gobierno de México, 2020, https://www.gob.mx/aem/articulos/a-10-anos-de-sucreacion-la-aem-ha-puesto-a-mexico-en-el-conciertomundial-del-desarrollo-cientifico-y-tecnologico249274? idiom=es, (accessed 03.06.20).

[10] S. Hirshorn, L. Voss and L. Bromley, "NASA Systems Engineering Handbook", third ed., NASA, Washington, United States, 2017, p. 37, https://ntrs.nasa.gov/citations/20170001761

[11] L. Woodmansee, "Lack of NASA Outreach Is a Setback to US Science", 2013, https://www.space.com/20468nasa-suspends-outreach.html, (accessed 08.06.20).

[12] D. Jakus, K. Zubcić, "Transmedia marketing and reinvention of public relations", MINIB, 22:4, (2016) 91102, http://minib.pl/en/transmedia-marketing-and-reinvention-of-public-relations/, (accessed 11.06.20).

[13] A. Sinha, "Six Reasons Branding Is More Important Than Ever Before", Entrepreneur, 2018, https://www.entrepreneur.com/article/313369, (accessed 11.06.20).

[14] S. Goodson, "Why Brand Building Is Important", Forbes, 2020 , https://www.forbes.com/sites/marketshare/2012/05/27/ why-brand-building-is-important/\#1914a8773006, (accessed 11.06.20).

[15] M. Healey, “¿Qué es el branding?”, Gustavo Gili, Barcelona, 2009, pp. 25
[16] A. Decker, "The Ultimate Guide to Branding in 2020", Hubspot, 2020, https://blog.hubspot.com/marketing/branding

[17] S. D. Kirby, M. K. Taylor, V. S. Freimuth, C. F. Parvanta, "Identity building and branding at CDC: A case study", Social Marketing Quarterly, 7:2, (2001), 1635 .

[18] T. Long, A. M. Taubenheim, J. Wayman, S. Temple, B. A. Ruoff, "The Heart Truth: Using the Power of Branding and Social Marketing to Increase Awareness of Heart Disease in Women", Social Marketing Quarterly, 14:3, (2008), 3-29.

[19] G. McMahon, "The science behind storytelling-and why it matters", 2013, http://blog.slideshare.net/2013/11/20/the-sciencebehind-storytelling-and-why-it-matters/, (accessed 18.06.20).

[20] D. Aaker, J. Aaker, "What are Your Signature Stories?", California Management Review, 58:3, (2016), 49-65, https://journals.sagepub.com/doi/pdf/10.1525/cmr.2016. 58.3.49.

[21] R. Smith, "Strategic planning for public relations", second ed. Mahwah, New Jersey, 2008.

[22] A. Hein, A. Tziolas, R. Osborne, "Project Icarus: Stakeholder Scenarios for an Interstellar Exploration Program”, IAC-10-D4.2.5, 61st International Astronautical Congress, Prague, Czech Republic, 2010, September 27 - October 1.

[23] F. Ackermann, C. Eden, "Strategic Management of Stakeholders: Theory and Practice", Long Range Planning, 44:3, (2011), 179-196, 10.1016/j.lrp.2010.08.001

[24] J. Cronin, "Teach students to communicate a brand story with transmedia storytelling", Journal of Research in Interactive Marketing, 10:2, (2016), 86-101, https://www.emerald.com/insight/content/doi/10.1108/J RIM-01-2015-0004/full/html.

[25] H. Jenkins, Transmedia Storytelling, MIT Technology Review, 2003, https://www.technologyreview.com/2003/01/15/234540 /transmedia-storytelling/, (accessed 25.06.20).

[26] H. Jenkins, "Searching for the Origami Unicorn: The Matrix and Transmedia Storytelling", in: Convergence Culture, New York University Press, New York, 2006, pp. 93-130.

[27] C. Dena, "Transmedia Practice: Theorising the Practice of Expressing a Fictional World across Distinct Media and Environments", Doctor of Philosophy (PhD), University of Sydney, Australia, 2009.

[28] C. Scolari, "Narrativas transmedia", Deusto, Barcelona, 2017, pp.351.

[29] R. Pratten, "Getting started in transmedia storytelling", second ed., CreateSpace, Seattle, 2015.

[30] C. Venturini, "Improving Mission Success of CubeSats", The Aerospace Corporation, California, USA, 2017, p. 42 - 79, https://aerospace.org/paper/improving-mission-successcubesats 